\title{
Design of an Efficient Cooling Tower for Alaoji Power Plant, Aba, Abia State, Nigeria
}

\author{
Ugwu, Hyginus Ubabuike \\ Department of Mechanical Engineering, Michael Okpara University of Agriculture, Umudike, \\ P.M.B. 7267, Umuahia, Abia State, Nigeria
}

\begin{abstract}
The work embodied in this study is to design a cooling tower that will effectively optimize the cooling effect of the condenser in Alaoji power station as a result of its heating effect. To achieve a better power efficiency output of the Combined Cycle Power Plant system existing in Alaoji power station, and to have an optimized cooling tower that could be adapted for different plants' configurations irrespective of their locations, made this study very significant. This study was carried out as a result of the problem faced by Alaoji Combined Cycle Power Plant with respect to the cooling of the condenser unit. By simply installing a well designed cooling tower, a solution was provided which effectively cooled the condenser. Also, with the introduction of the cooling tower, the heating effect of the condenser was eventually stabilized to a temperature of $30^{\circ} \mathrm{C}$ which consequently cooled the condenser. However, with the absence of the cooling tower prior to its installation, the temperature rises to about $35-40^{\circ} \mathrm{C}$. Though the overall efficiency of the steam plant calculated without the unit was actually $33.85 \%$, an achievement and success with the introduction of the cooling tower increased the condenser's efficiency from $33.94 \%$ to $66.26 \%$ which improved the system's performance considerably. More so, an induced blower with a concrete structure was used for the design of the cooling tower.
\end{abstract}

Keywords: Alaoji power station, combined cycle power plant, condenser unit efficiency with induced blower, cooling tower heating effect, optimizing power efficiency output

\section{INTRODUCTION}

Cooling towers are very important part of many chemical plants. The primary task of a cooling tower is to reject heat into the atmosphere. They represent a relatively inexpensive and dependable means of removing low-grade heat from cooling water. The make-up water source is used to replenish water lost to evaporation, just like the hot water from the heat exchangers is sent to the cooling tower. The water exits the cooling tower and is sent back to the exchangers or to other units for further cooling. Typical closed loop cooling tower system is shown in Fig. 1 [1].

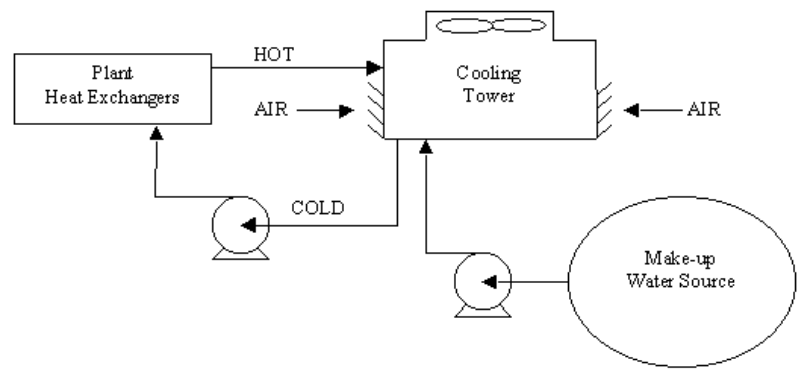

Fig. 1: Typical closed loop cooling tower system

Alaoji power plant is used as a case study for this work. It is a Combined Cycle Power Plant (CCPP) system that utilizes Wet Surface Air Cooler (WSAC) as its cooling option. Alaoji power plant is a Power Holding Company of Nigeria (PHCN) Plc and National Integrated Power Project (NIPP) facility with a stipulated output of $1074 \mathrm{MW}$. The project is being handled by Rockson Engineering (RE) Company, Limited and General Electricity (GE) Company, Limited with their offices situated in Port Harcourt, Nigeria. The power plant itself is located in Aba, Abia State and is usually 5 to $8^{\circ} \mathrm{C}$ hotter than the neighbouring cities [2]. According to the source, Aba registers ambient of about $40^{\circ} \mathrm{C}$ when Port Harcourt ( $35 \mathrm{~km}$ from Aba) is $32^{\circ} \mathrm{C}$ or less in the months of December to March. Hence, the range of temperature variation in Alaoji is usually between $24^{\circ} \mathrm{C}$ and $40^{\circ} \mathrm{C}$. However, there are few exceptions when the ambient was $16^{\circ} \mathrm{C}$ and $43^{\circ} \mathrm{C}$ as recorded [2].

Even though the scope of this study included the initial concept of the original design (which was conceived by RE and an improvement in her design, the sourcing of materials for the plant layout in Alaoji power station, the selection of the materials for an efficient cooling tower design, and the design consideration for high effectiveness), the study however, is limited to the design of an efficient cooling tower that will effectively cool the condenser unit. This is to stabilize its heating effect for optimum performance of the system as it relates to Alaoji power plant. Also, since the degree of useful work of any engineering design is measured by the pedigrees of its economic importance, in terms of its cost effectiveness, safe operating procedure, and ease of operation, these parameters necessitated the desire to carry out the study. 


\section{REVIEW OF COOLING METHODS USED IN ALAOJI POWER STATION}

\section{II.1 Alaoji CCPP Cooling Solution}

Steam turbine (ST) plant is optimized by the cooling method used for the condensation of the ST exhaust steam. This has a direct relationship with the back pressure on the ST exhausting steam which also affects the thermal and power efficiency of the plant [3]. There are three identified cooling methods in use in Alaoji CCPP station. These are as listed below and presented in Table 1 .

i. Wet cooling technology-example: cooling tower.

ii. Dry cooling technology-example: ACC (Air Cooled Condenser); and

iii. Hybrid cooling technology-example: WASC (Wet Surface Air Cooler) [2].

Table 1: Consumption Rate of Raw Water for the Different Options of Cooling in Alaoji CCPP.

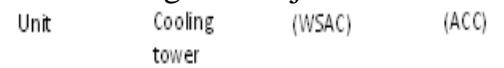

\begin{tabular}{|lcccc|}
\hline $\begin{array}{l}\text { Water for cooling } \\
\mathrm{m} / \mathrm{hr}\end{array}$ & 1,475 & 200 & Nil \\
\hline $\begin{array}{l}\mathrm{m} / \mathrm{hr} \\
\text { Blow down }\end{array}$ & 98 & 30 & Nil \\
\hline $\begin{array}{l}\text { Pond fill period } \\
\text { days }\end{array}$ & 60 & 250 & NH \\
\hline
\end{tabular}

From Table 1, it is evident that the first option is the most efficient of the three technologies followed by the third option, while the second option is the least efficient of the three as identified.

Alaoji is not located close to any water body (river or sea). Hence, the only water source for the plant operation is from well water. The water requirements of the cooling tower and WSAC cannot be sustained from the well water for the power plant life of 30years. Another major area of concern is the evacuation of the plant retention pond for catching the plant run-off water and the blow downs. This will not be the issue with the dry cooling technology. Without the process water, the retention pond $\left(189,000 \mathrm{~m}^{3}\right)$ will never be filled up. Hence, the issue of evacuation is completely eliminated.

\section{II.1.1 Comparison between ACC and WSAC}

Since it is obvious that water is not available for the adoption of cooling tower for Alaoji cooling solution, there was need to compare WSAC and ACC as envisaged by the company to determine the best option for water supply adoptable. These are presented as in Table 2. Based on these, it was identified that WSAC required more equipment than ACC which implied that WSAC will demand more cost than ACC.

Table 2: Comparison between WSAC and ACC Water Supply Requirement for Alaoji CCPP.
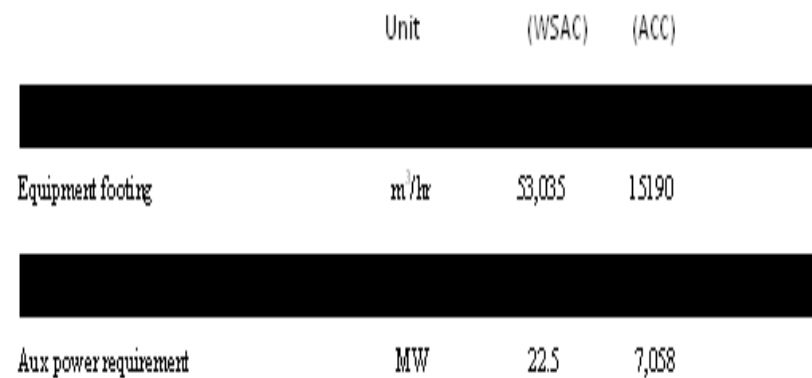

\section{II.1.2 Commercial Comparison between ACC and} WSAC

a. WSAC

Table 3: Estimated Installation Cost of WSAC for Alaoji CCPP.

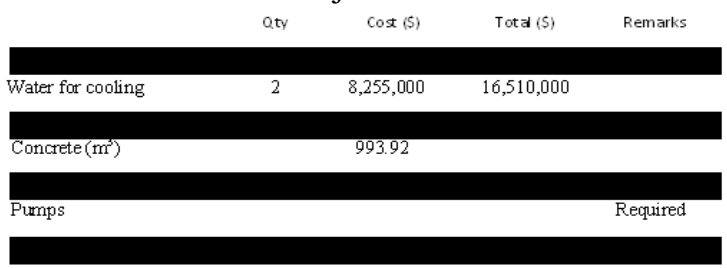

b. ACC

Table 4: Estimated Installation Cost of ACC for Alaoji CCPP.

$$
\text { Q.ty Cost }(\$) \text { Total }(\$) \text { Remals }
$$

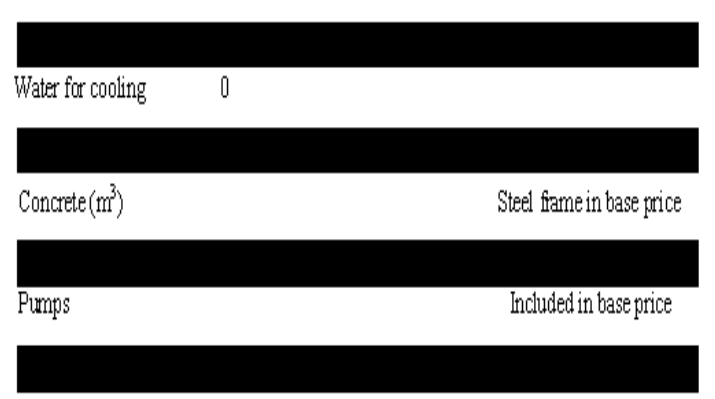

Commercially, as depicted in Tables 3 and 4, ACC appeared to be the better choice for Alaoji CCPP since the entire package handling the exhaust steam from the lower pressure (LP) ST to the condenser in the hot well, is completely handled by a vendor at a lump sum. Conversely, WSAC installation required at least three different vendors for the following sections of equipment:

- Wet section of WSAC.

- Dry section of WSAC.

- Steam surface condensers (SSC).

- Interconnecting piping from the SSC to WSAC; and

- Pumps. 
Hence, in economic terms, ACC was identified to be the best option against the WSAC to be adopted for Alaoji CCPP operations for effective cooling.

\section{II.2 ACC for Alaoji CCPP}

Steam from the ST exhaust flows through the main stream duct to the roof-shaped air-cooled condenser where it is then condensed inside the heat exchangers using ambient air as the cooling medium. The cooling air is provided by axial fans, which are attached to electric motors via speed reducing gearboxes. At the bottom of the heat exchangers, there is a tank which is partially reheated with the steam coming from the main stream duct via the equalization line. The condensate from the condensate tank (hotwell) is then pumped to the boiler feed water system to complete the closed cycle.

\section{II.2. 1 Alaoji Ambient Temperature}

Ambient temperatures have direct impact on the steam turbine back pressure (Tbp), which consequently bear and affect the thermal and power efficiency of the Plant. The efficiency of ACC is extremely dependent on the ambient dry-bulb temperature (DBT).

Aba, a major commercial hub and city in Nigeria where Alaoji is located is usually $5^{\circ} \mathrm{C}$ to $8^{\circ} \mathrm{C}$ hotter than the neighbouring cities of other states. It registers an ambient temperature of $40^{\circ} \mathrm{C}$, when Port Harcourt, Rivers State (35km from $\mathrm{Aba})$ records $32^{\circ} \mathrm{C}$ or less in the months of December to March [2].

Although, RE has a contractual obligation to build Alaoji CCPP at a performance guarantee ambient temperature of $32^{\circ} \mathrm{C}$, studies have shown that this temperature is rarely achievable between $10.00 \mathrm{hrs}$ and $19.00 \mathrm{hrs}$ as recorded in the month of April 2009 in a study to determine the hourly temperature reading for that location [2]. Also, a similar study by RE [2] to determine the heat balance diagram (HBD) of Alaoji power plant indicated that the plant has a Tbp of $4.04 \mathrm{HgA}(0.1368 \mathrm{bar})$ at a guarantee ambient of $32^{\circ} \mathrm{C}$. However, Tbp is expected to be higher when the ambient temperature increases.

\section{II.3 Alaoji ST Performances with ACC}

The variations of steam Tbp have direct impact on its thermodynamic performance, likewise on the power output [2]. This is presented as in Table 5 showing the operational limit of the ST.
Table 5: Alaoji Steam Turbine Performance with ACC
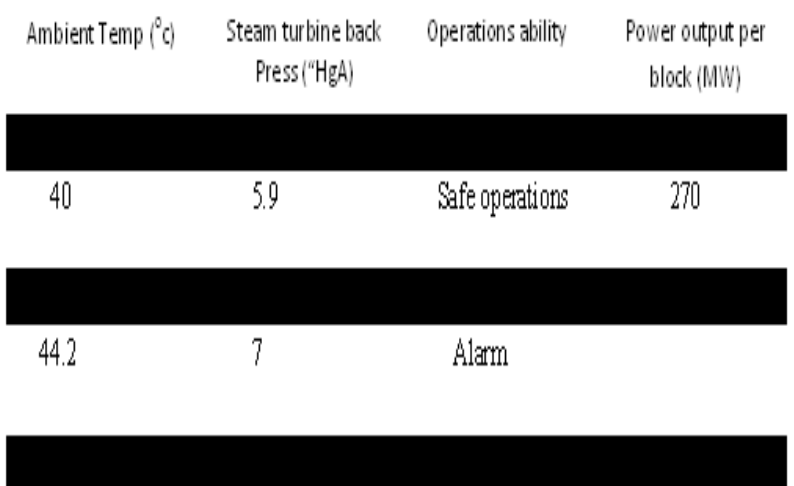

From the Table, it is evident that at a temperature of $40^{\circ} \mathrm{C}$ and a pressure of $5.9 \mathrm{HgA}$, the ST is safe to be operated and will produce a power output of $270 \mathrm{MW}$ per block, while at $44.2^{\circ} \mathrm{C}$ and $7 \mathrm{HgA}$, it is very unsafe to be operated, and should be check-mated.

\section{MATERIALS AND METHODS}

III.1 Design Calculations/Observations and Analyses The materials involved in this design are the component parts of the steam power plant. These, have been methodologically, systematically and sequentially analyzed to obtain the overall condenser efficiency suitable for the cooling tower optimized performance. In making the analyses, literature materials obtained from standard steam properties tables and standard formulations (equations) were consulted and used.

The design of the cooling tower involves the analyses of the operational sequence of the steam plant as shown in Fig. 2, which presents the various stages of the steam power plant processes as utilized in Alaoji CCPP station.

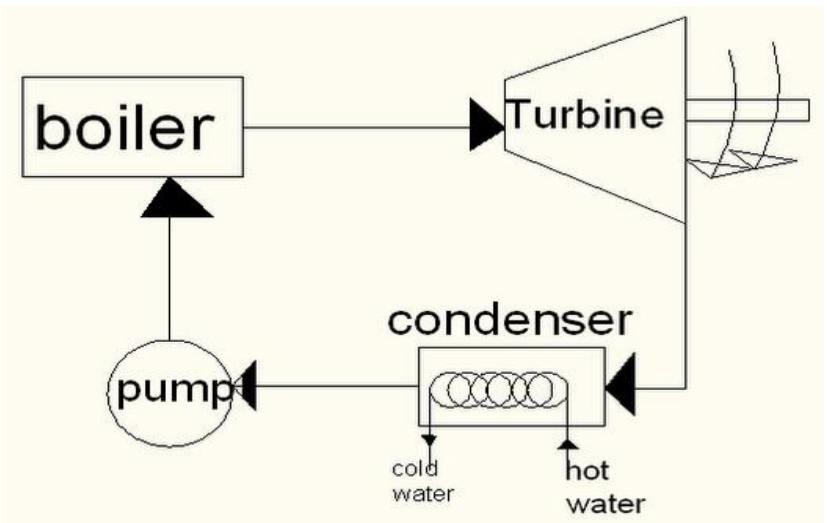

Fig. 2: Schematic diagram of the steam plant configuration in Alaoji CCPP station

III.1.1 Boiler

The boiler used in Alaoji power plant is a water- tube type. Before operation, the energy needed to start the operation is 
IOSR Journal of Engineering

Apr. 2012, Vol. 2(4) pp: 731-737

gotten from the heat gained from the exhaust of the gas plant. This raised the pressure of the water to about 30.63 bars at a temperature of $235^{\circ} \mathrm{C}(508 \mathrm{~K})$. At this point, the steam generated had enough energy to operate the steam turbine.

\section{III.1.2 Turbine}

As the turbine does work, the exhaust steam from the turbine was condensed in the condenser to a pressure and temperature of about 0.0425 bar and $30^{\circ} \mathrm{C}$, respectively. At that point, the condensed steam was redirected back into the boiler by a heat pump. The major problem encountered in the operation, was that as time went on, the temperature of the condenser gradually started increasing and hence, its ability to condense the steam began to reduce. This resulted in the existence of both steam and water after the condensation process, thus reducing the performance and efficiency of the steam plant. As a result, there was a dire need for a cooling tower to be installed to maintain the temperature of the condenser to normalcy. The whole process of operation obtained for Alaoji power plant is as presented in a temperature-entropy (T-s) diagram shown in figure 3 .

\section{III.1.3 Parameters Specification and Designation}

From the Steam Properties Table [4], these parameters were specified (Fig. 3).

At point $1: \mathrm{P}=30.63$ bar; $\mathrm{T}_{1}=235^{\circ} \mathrm{C}(508 \mathrm{~K})$;

$$
\begin{aligned}
& \mathrm{h}_{1}=2803.1 \mathrm{KJ} / \mathrm{Kg} ; \text { and } \\
& \mathrm{S}_{\mathrm{g}}=6.1777 \mathrm{KJ} / \mathrm{KgK} .
\end{aligned}
$$

At point $2^{\prime}: \mathrm{P}=0.0563 \mathrm{bar} ; \mathrm{T}_{2}^{\prime}=35^{\circ} \mathrm{C}(308 \mathrm{~K})$;

$\mathrm{h}_{\mathrm{f}}=146.6 \mathrm{KJ} / \mathrm{Kg} ; \mathrm{h}_{\mathrm{g}}=2564.4 \mathrm{KJ} / \mathrm{Kg}$;

$\mathrm{S}_{\mathrm{f}}=0.5050 \mathrm{KJ} / \mathrm{KgK} ;$ and

$\mathrm{S}_{\mathrm{g}}=8.3511 \mathrm{KJ} / \mathrm{KgK}$.

At point $2: \mathrm{P}=0.0425 \mathrm{bar} ; \mathrm{T}_{2}=30^{\circ} \mathrm{C}(303 \mathrm{~K})$; $\mathrm{h}_{\mathrm{f}}=125.7 \mathrm{KJ} / \mathrm{Kg}$; and $\mathrm{h}_{\mathrm{g}}=2555.3 \mathrm{KJ} / \mathrm{Kg}$.

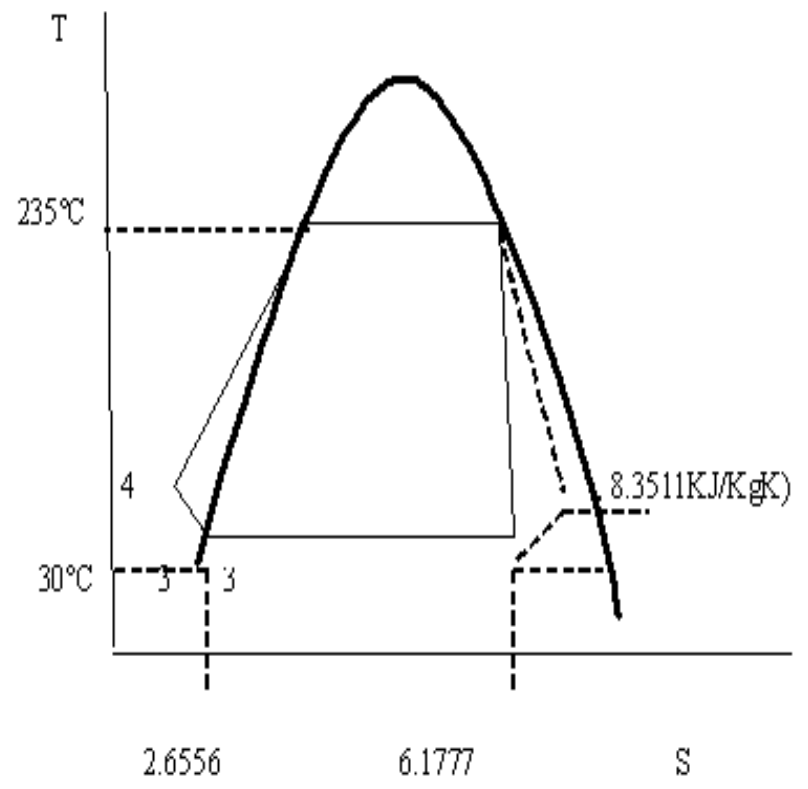

Fig. 3: Temperature-entropy (T-s) diagram of Alaoji cooling process

With these data, the efficiency of the steam plant and the designing parameters for the cooling tower were estimated. Hence, the turbine work, $\mathrm{W}_{\mathrm{T}}$ is given by:

Where:

$$
\mathrm{W}_{\mathrm{T}}=\left[h_{1}-h_{2}\right]-W_{P}[5]
$$

$\mathrm{W}_{\mathrm{T}}=$ Work done by the steam turbine, and

$\mathrm{W}_{\mathrm{P}}=$ Work exerted by the pump $\left(\mathrm{h}_{1}=\mathrm{h}_{4}=2803.1 \mathrm{KJ} / \mathrm{Kg}\right.$ at 30.63 bar).

Since: $S_{1}=S_{2}=6.1777 \mathrm{KJ} / \mathrm{KgK}$, then:

Thus:

$$
\mathrm{S}_{2}=S_{f}+X_{2}\left(S_{g}-S_{f}\right)[5]
$$

$6.1777=0.5050+X_{2}(8.3511-0.5050)$

$$
\begin{array}{r}
X_{2}=\frac{6.1777-0.5050}{8.3511-0.5050}=\frac{5.6727}{7.8461} \\
\therefore X_{2}=0.723=\text { the Quality of the fluid }
\end{array}
$$

Similarly,

$$
\begin{gathered}
\mathrm{h}_{2}=h_{f}+X_{2}\left(h_{g}-h_{f}\right) \\
\mathrm{h}_{2}=146.6+0.723(2564.4-146.6) \\
\mathrm{h}_{2}=146.6+0.723(2417.8)=146.6+1748.0694 \\
\therefore \mathrm{h}_{2}=1894.67 \mathrm{KJ} / \mathrm{Kg}
\end{gathered}
$$

III.1.4 The Pump Work of the Turbine

The pump work of the turbine, $\mathrm{Wp}$ is given by:

Where:

$$
\mathrm{W}_{\mathrm{P}}=v \Delta_{P}(\text { pump work })
$$


$v=$ The specific volume at $0.0425 \mathrm{bar}=0.001004 \mathrm{~m}^{3} / \mathrm{Kg}$; and $\Delta_{P}=$ the change in pressure $\left(\mathrm{P}_{1}-\mathrm{P}_{2}\right)$. Thus:

$$
\begin{aligned}
\mathrm{W}_{\mathrm{P}}= & 0.001004(30.63-0.0425) 100 \\
= & 0.001004(30.5875) 100 \\
& \therefore W_{P}=3.07 \mathrm{KJ} / \mathrm{Kg}
\end{aligned}
$$

\section{III.1.5 The Turbine Work, $\mathbf{W}_{\mathrm{T}}$}

Recall: the turbine work, $\mathrm{W}_{\mathrm{T}}(1)$ is given by:

Hence:

$$
\mathrm{W}_{\mathrm{T}}=\left[h_{1}-h_{2}\right]-W_{P}
$$

$$
\begin{gathered}
\mathrm{W}_{\mathrm{T}}=(2803.1-1894.67)-3.07=908.43-3.07 \\
\therefore W_{T}=905.36 \mathrm{KJ} / \mathrm{Kg}
\end{gathered}
$$

\section{III.1.6 Specific Steam Consumption}

This is given by:

$$
\begin{gathered}
\mathrm{SSC}^{\prime}=\left(\frac{1}{h_{1}-h_{2}}\right) \\
\mathrm{SSC}^{\prime}=\left(\frac{1}{2803.1-1894.67}\right)=\frac{1}{908.43}
\end{gathered}
$$

$$
\therefore \mathrm{SSC}^{\prime}=0.0011008 \mathrm{Kg} / \mathrm{KJ} \text { or } 1.1 \times 10^{-3} \mathrm{Kg} / \mathrm{KJ}
$$

\section{III.1.7 The Condenser Heating Load}

The condenser heating load, Q' (energy involved in heating the condenser load) is obtained as:

$$
\mathrm{Q}^{\prime}=\operatorname{SSC}^{\prime}\left(\mathrm{h}_{2}-\mathrm{h}_{3}\right)
$$

Thus:

But: $\mathrm{h}_{3}=\mathrm{h}_{\mathrm{f} 2}=125.7 \mathrm{KJ} / \mathrm{Kg}$

$$
\begin{gathered}
Q^{\prime}=1.1 \times 10^{-3}(1894.67-125.7)=1.1 \times 10^{-3}(1768.97) \\
\therefore Q^{\prime}=1.946 \mathrm{KW} \text { per KW output }
\end{gathered}
$$

Or 1.946:1 (ratio of the heat load of the condenser to its output work).

\section{III.2 Design Parameters of the Cooling Tower}

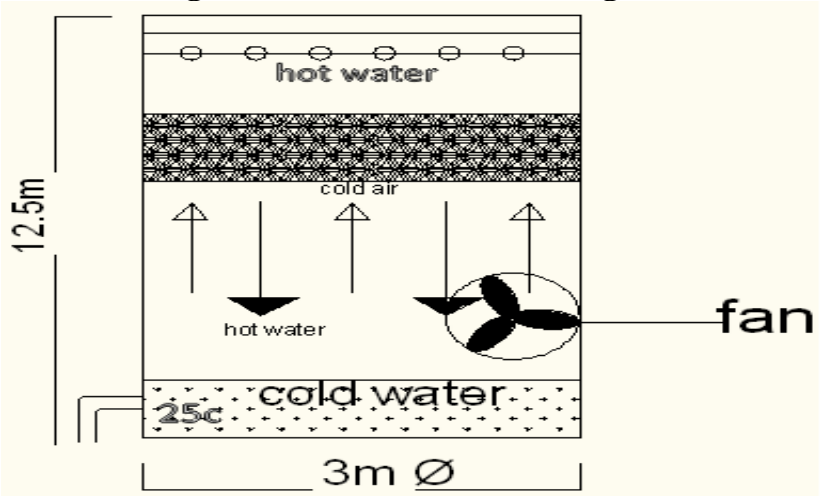

Fig. 4: Schematic of a cooling tower in Alaoji power Station
The schematic of a cooling tower existing in Alaoji power station presented in Fig. 4 enables the determination of its design parameters. This is to assist in the optimization of the condenser in order to compensate for the heating up of the condensation. By comparing the mass flow rates of the cold air needed to subdue the heat from the hot water in the cooling tower, the relations (7a) and (7b) are obtained. Hence:

$$
\text { Heat gained by air }=\text { Heat rejected by water }
$$

Mathematically, it is stated as:

$$
m_{a} c_{a} \theta_{a}=m_{w} c_{w} \theta_{w}
$$

Where:

$\mathrm{m}_{\mathrm{a}}, \mathrm{m}_{\mathrm{w}}=$ Masses of air and water;

$\mathrm{C}_{\mathrm{a}}, \mathrm{C}_{\mathrm{w}}=$ Specific heat capacities of air and water; and $\theta_{a}, \theta_{w}=$ Temperatures of air and water, respectively.

The cooling tower is such that the air gets to the hot water by a forced induction in which case, the forcing inducer is a discharge blower. Hence, the design takes the shape as depicted in Fig. 4 where its parameters are as specified thus:

The diameter of the tower $=3 \mathrm{~m}$;

The height of the tower $=12.5 \mathrm{~m}$;

The speed of the fan (blower) $=1800 \mathrm{rpm}$;

The diameter of the blade in motion $=1 \mathrm{~m}$; and

The temperature of the air blown by fan $=20^{\circ} \mathrm{C}(293 \mathrm{~K})$.

III.2.1 The Velocity of the Air Stream from the Blower The velocity of the air stream from the blower is given by:

$$
\text { Velocity, } \mathrm{V}=\frac{\pi D N}{60}
$$

Thus:

$$
\begin{gathered}
\mathrm{V}=\frac{3.142 \times 1 \times 1800}{60}=\frac{5655.6}{60} \\
\therefore \mathrm{V}=94.26 \mathrm{~m} / \mathrm{s}
\end{gathered}
$$

III.2.2 The Area of the Cooling Tower

Since the diameter of the tower is $3 \mathrm{~m}$, then:

$$
\text { Area, } \mathrm{A}=\pi \mathrm{r}^{2}
$$

Hence:

$$
\begin{gathered}
\mathrm{A}=3.142 \times(1.5)^{2}=3.142 \times 2.25 \\
\therefore \mathrm{A}=7.0695 \text { approx. } 7.070 \mathrm{~m}^{2}
\end{gathered}
$$

III.2.3 The Discharge of the Air Stream The discharge of the air stream is given by:

Thus:

$$
\mathrm{Q}=\mathrm{AV}
$$

$$
\mathrm{Q}=7.070 \times 94.26=666.42 \mathrm{~m}^{3} / \mathrm{s}
$$




\section{III.2.4 The Mass of the Air Stream, $\mathrm{m}_{\mathrm{a}}{ }^{\text {, }}$ This is given by:}

But:

$$
\mathrm{m}_{\mathrm{a}^{\prime}}=(\text { density } \mathrm{x} \text { discharge })=\rho_{a} Q
$$

The density of air, $\rho_{a}=1.01 \mathrm{Kg} / \mathrm{m}^{3}$; thus:

$$
\mathrm{m}_{\mathrm{a}^{\prime}}=1.01 \times 666.42=673.08 \mathrm{Kg} / \mathrm{s}
$$

III.2.5 The Mass Flow Rate of Water in the Cooling Tower, $\mathrm{m}_{\mathrm{w}}$ Invoking (7b), the mass flow rate of water, $\mathrm{m}_{\mathrm{w}}$ is obtained as:

Where:

$$
m_{w}=\frac{m_{a} c_{a} \theta_{a}}{c_{w} \theta_{w}}
$$

$\theta_{a}=$ the temperature difference between the ambient and the temperature of air by the blower;

$\theta_{w}=$ the temperature difference between the ambient and the cold water in the cooling tower; and

$m_{w}=$ the mass flow rate of water in the cooling tower, respectively.

Hence:

$$
\begin{gathered}
m_{w}=\frac{673.08 \times 1.003 \times(32-20)}{4.183 \times(32-25)}=\frac{673.08 \times 1.003 \times 12}{4.183 \times 7} \\
\therefore m_{w}=\frac{8101.191}{29.281}=276.67 \mathrm{Kg} / \mathrm{s}
\end{gathered}
$$

\section{III.2.6 The Cooling Effect of the Condenser}

Using the cold water flow rate, $m_{w}$, the cooling effect of the condenser, Q"' can be calculated thus:

$$
\mathrm{Q}^{\prime \prime}=m_{w} x c_{w} x d \theta_{C}
$$

Where:

$d \theta_{C}=$ The difference between the temperature of the condenser before $\left(\mathrm{T}_{2}{ }^{\prime}\right)$, and after the installation of the cooling tower $\left(\mathrm{T}_{2}\right)$, respectively (See Fig. 3 and section 3.1.3: specification and parameters designation).

Thus:

$$
\begin{aligned}
& Q^{\prime \prime}=276.67 \times 4.183 \times(35-30) \\
& =276.67 \times 4.183 \times 5 \\
& \therefore \quad Q^{\prime \prime}=5786.55 \mathrm{~W} \text { or } 5.787 \mathrm{KW}
\end{aligned}
$$

\section{III.3 The Efficiency of the System}

To calculate the efficiency of the system, (14) is used. Thus:

$$
\begin{aligned}
& \text { Efficiency, } \eta=\frac{W_{T}-W_{P}}{Q_{1}} \\
& \quad \eta 7] \\
& \eta=\frac{908.43-3.07}{Q_{1}}=\frac{905.36}{Q_{1}}
\end{aligned}
$$

Where: $Q_{1}=$ heat added into the system

$$
\text { But: } \quad \mathrm{h}_{4}=\mathrm{h}_{3}+\mathrm{W}_{\mathrm{P}}
$$

Recall: $\mathrm{h}_{3}=\mathrm{h}_{\mathrm{f} 2}=125.7 \mathrm{KJ} / \mathrm{Kg}$

Hence, from (16):

$$
\mathrm{h}_{4}=125.7+3.07=128.77 \mathrm{KJ} / \mathrm{Kg}
$$

Similarly, recall also that for pump work $\left(\mathrm{W}_{\mathrm{P}}\right)$, $\mathrm{h}_{1}=\mathrm{h}_{4}$; this implies that:

$$
Q_{1}=\mathrm{h}_{1}-\mathrm{h}_{4}
$$

Thus: $\quad Q_{1}=2803.1-128.77=2674.33 \mathrm{KJ} / \mathrm{Kg}$

$$
\therefore \eta=\frac{905.36}{Q_{1}}=\frac{905.36}{2674.33}=0.3385 \text { or } 33.85 \%
$$

\section{III.4 Total Energy of the Condenser System This is given by:}

$$
\begin{gathered}
\text { Total energy } \\
=\text { work due to heat loss }+ \text { output work }
\end{gathered}
$$

But recall that the ratio of the heat load of the condenser to its output work $=1.946$ : 1 ; hence:

$$
\begin{gathered}
\text { Total energy }=1.946+1=2.946 \mathrm{KW} \\
\therefore \eta=\frac{1}{2.946} \times 100=33.94 \%
\end{gathered}
$$

Since the cooling effect provided by the cooling tower is $5.787 \mathrm{kw}$ of the power, then the balance between the cooling effect and the heating load effect thus becomes:

$$
\begin{gathered}
(1.946+1): 5.787 \\
\text { Or } 2.946: 5.787=1: 1.964
\end{gathered}
$$

Hence, the total energy of both the condenser and the cooling tower now becomes: $(1+1.964)=2.964 \mathrm{KW}$.

This gives 1.964 times of cooling effect to the heating effect. Thus, the efficiency of the condenser due to the cooling tower finally becomes:

$$
\eta_{C}=\frac{1.964}{2.964} \times 100=\frac{196.4}{2.964}=66.26 \%
$$

This means that there is an increase in the efficiency of the condenser due to the installation of the cooling tower from $33.94 \%$ to $66.26 \%$, respectively. 


\section{CONCLUSION}

The need for cooling tower in today's industries cannot be over-emphasised. An effective cooling tower has been designed for Alaoji Power Plant, putting all the necessary conditions into play.

By simply installation a well designed cooling tower, a solution was provided which effectively cooled the condenser by stabilizing its temperature to $30^{\circ} \mathrm{C}$. Prior to its installation, the temperature of the system usually rises to about $35-40^{\circ} \mathrm{C}$. However, after the installation, the overall efficiency of the condenser increased from $33.94 \%$ to $66.26 \%$ from its calculated overall efficiency of $33.85 \%$, which thus improved the system's performance tremendously. This was done utilizing an induced blower with a concrete structure.

Also, from the design, it was inferred that an efficient cooling tower should be such that the ambient wet bulb temperature is specified, since there is no initial knowledge or control over the recirculation factor. Similarly, the wet bulb temperature usually determined by the geographical location, should not exceed over 5 percent of the time in that area because the higher the wet bulb temperature, the smaller the tower required to give a specified approach to the wet bulb at a constant range and flow rate.

\section{RECOMMENDATION}

Having concluded this design, it is recommend that:

- The ambient temperature of Aba, Abia State, should always be considered when making any modifications on Alaoji Power Plant.

- A combined cycle type of cooling tower is used in Alaoji. This will help check-mate the irregularities in the ambient temperatures of the site where the cooling tower is located.

- In the selection of the size, proper care should be taken so as to select a cooling tower suitable for a particular function.

- By evaluating the cost and size of the heat exchangers versus the cost and size of the cooling tower, the quantity and temperature of the cooling tower water can be selected to get the maximum economy for a particular process.

- Effective care should also be taken during CT selection, so as not to exceed the rated parameters; and A good maintenance planning procedures should be properly prepared for the smooth running of the cooling tower.

\section{ACKNOWLEDGEMENTS}

The author wishes to acknowledge the efforts made by Ikeji Adindu and Ndumele Ufomadu of the Department of Mechanical Engineering, Michael Okpara University of Agriculture, Umudike, Umuahia, Abia State in sourcing the data and information that enabled the analyses of the study to be consolidated. Also, worthy of commendation are the high level of understanding and total commitments shown by the staff and management of Alaoji Power Station, Aba, Abia State in releasing and availing us with useful and relevant data and literature materials that assisted in the analyses.

\section{REFERENCES}

[1] H. John, Cooling Towers System Guidance for Energy Operations, Kelcroft E \& M Limited, 1988, pp.1- 6.

[2] Rockson Engineering, Alaoji Combined Cycle Power Plant: Economic and Performance Evaluation of Heat Sink Options in Alaoji Combined Cycle Application, Aba, Nigeria, 2009.

[3] G. Walker, Industrial Heat Exchangers, $2^{\text {nd }}$ Edition, Mc Graw-Hill, 1990.

[4] W.P. Jones, Air Conditioning Engineering, 3rd Edition, Edward Arnold, 1985.

[5] T.D Eastop, A. Mc Conkey, Applied Thermodynamics for Engineering Technologists, 1993.

[6] E.R. Eckret, R.M. Drake, Analysis of Heat and Mass Transfer, Taylor and Francis, 1971.

[7] T.D. Eastop, D.R. Croft, Energy Efficiency, Longman, 1990. 